\title{
Comparison of the Novel Antipsychotic Ziprasidone with Clozapine and Olanzapine: Inhibition of Dorsal Raphe Cell Firing and the Role of $5-\mathrm{HT}_{1 \mathrm{~A}}$ Receptor Activation
}

\author{
Jeffrey S. Sprouse, Ph.D., Linda S. Reynolds, M.S., John P. Braselton, B.S.,
} Hans Rollema, Ph.D., and Stevin H. Zorn, Ph.D.

Ziprasidone is a novel antipsychotic agent which binds with high affinity to $5-H T_{1 A}$ receptors $\left(K_{i}=3.4 n M\right)$, in addition to $5-H T_{1 D}, 5-H T_{2}$, and $\mathrm{D}_{2}$ sites. While it is an antagonist at these latter receptors, ziprasidone behaves as a $5-H T_{1 A}$ agonist in vitro in adenylate cyclase measurements. The goal of the present study was to examine the $5-H T_{1 A}$ properties of ziprasidone in vivo using as a marker of central 5-HT $1 A$ activity the inhibition of firing of serotonincontaining neurons in the dorsal raphe nucleus. In anesthetized rats, ziprasidone dose-dependently slowed raphe unit activity $\left(E D_{50}=300 \mu \mathrm{g} / \mathrm{kg} \mathrm{IV}\right)$ as did the atypical antipsychotics clozapine $\left(E D_{50}=250 \mu \mathrm{g} / \mathrm{kg} I V\right)$ and olanzapine $\left(E D_{50}=1000 \mu \mathrm{g} / \mathrm{kg} \mathrm{IV}\right)$. Pretreatment with the 5-HT ${ }_{1 A}$ antagonist WAY-100,635 (10 $\left.\mu \mathrm{g} / \mathrm{kg} \mathrm{IV}\right)$ prevented the ziprasidone-induced inhibition; the same dose of WAY-100,635 had little effect on the inhibition produced by clozapine and olanzapine. Because all three agents also bind to $\alpha_{1}$ receptors, antagonists of which inhibit serotonin neuronal firing, this aspect of their pharmacology was assessed with desipramine (DMI), a NE re-uptake blocker previously shown to reverse the effects of $\alpha_{1}$ antagonists on raphe unit activity. DMI $(5 \mathrm{mg} / \mathrm{kg} \mathrm{IV})$ failed to reverse the inhibitory effect of ziprasidone but produced nearly complete reversal of that of clozapine and olanzapine. These profiles suggest a mechanism of action for each agent, 5-HT $\mathrm{T}_{1 A}$ agonism for ziprasidone and $\alpha_{1}$ antagonism for clozapine and olanzapine. The $5-H T_{1 A}$ agonist activity reported here clearly distinguishes ziprasidone from currently available antipsychotic agents and suggests that this property may play a significant role in its pharmacologic actions. [Neuropsychopharmacology 21:622-631, 1999] (C) 1999 American College of Neuropsychopharmacology. Published by Elsevier Science Inc.
KEY WORDS: Antipsychotic; 5-HT ${ }_{1 A}$ Agonist;

Dorsal raphe nucleus; Electrophysiology

The current wave of atypical antipsychotics in various stages of clinical development has been spurred in part

From the Department of Neuroscience, Central Research Division, Pfizer Inc., Groton, CT.

Address correspondence to: Dr. Jeffrey Sprouse, Department of Neuroscience, Central Research Division, Pfizer Inc., Groton, CT 06340.

Received December 3, 1998; revised April 19, 1999; accepted April 29, 1999. by the shortcomings apparent in classical dopamine (DA) $\mathrm{D}_{2}$ receptor antagonists-low efficacy against negative symptoms and high propensity for extrapyramidal side effects (EPS) (Meltzer 1995). While no single agent is 'typical' of these atypicals, clozapine shares several pharmacological features with other members of this class, in particular, high affinity for $5-\mathrm{HT}_{2}$ receptors in addition to $\mathrm{D}_{2}$ sites (Altar et al. 1986; Meltzer et al. 1989). Its superior efficacy and reduced EPS liability has precipitated a re-evaluation of theories of schizophrenic pathology, resulting in a reinvigorated role for serotonergic systems in both cause and treatment 
Table 1. Binding affinities of ziprasidone, clozapine and olanzapine for rat $\mathrm{D}_{2}, 5-\mathrm{HT}_{2 \mathrm{~A}}, 5-\mathrm{HT}_{1 \mathrm{~A}}$, and $\alpha_{1}$ receptors ${ }^{a}$

\begin{tabular}{lcccc}
\hline $\mathbf{K}_{\mathbf{i}}(\mathbf{n M})$ & $\mathbf{D}_{\mathbf{2}}$ & $\mathbf{5 - H T}_{\mathbf{2 A}}$ & $\mathbf{5 - H T}_{\mathbf{1 A}}$ & $\alpha_{\mathbf{1}}$ \\
\hline Ziprasidone & 4.8 & 0.42 & 3.4 & 11 \\
Clozapine & 83 & 16 & 120 & 5.6 \\
Olanzapine & 11 & 6.2 & 2800 & 19 \\
\hline
\end{tabular}

${ }^{a}$ All data were compiled from Seeger et al. (1995), Howard et al. (1996), and Zorn et al. (1999).

(Sharma and Shapiro 1996). A focus on the 5- $\mathrm{HT}_{2}$ properties of clozapine is thus justified, and yet the binding affinity of clozapine to the $5-\mathrm{HT}_{1 \mathrm{~A}}$ receptor (Table 1) hints at the relative importance of this 5-HT subtype to the pharmacology of clozapine (Newman-Tancredi et al. 1996; Schotte et al. 1996). Recently reported interactions of $5-\mathrm{HT}_{1 \mathrm{~A}}$ agonists with $\mathrm{DA}$ neurotransmission suggest that the relief of negative symptoms obtained with clozapine and its reduced risk of motor dysfunction are due in part to its $5-\mathrm{HT}_{1 \mathrm{~A}}$ agonist properties (Sharma and Shapiro 1996).

Ziprasidone (Figure 1) is a novel antipsychotic agent, chemically unrelated to any available antipsychotic (Howard et al. 1996), with a unique combination of pharmacological activities at serotonergic, dopaminergic, and adrenergic receptors and transporters (Seeger et al. 1995; Schmidt et al. 1998). The high affinity binding of ziprasidone for $5-\mathrm{HT}_{1 \mathrm{~A}}, 5-\mathrm{HT}_{1 \mathrm{D}}$, and $5-\mathrm{HT}_{2 \mathrm{C}}$ receptors, in addition to the $5-\mathrm{HT}_{2 \mathrm{~A}}$ and $\mathrm{D}_{2}$ ones, differentiates it from other antipsychotics such as clozapine and its structural analog olanzapine, and places it outside the already heterogeneous category of atypical antipsychotics. While ziprasidone possesses $5-\mathrm{HT}_{1 \mathrm{~A}}$ agonist ac-

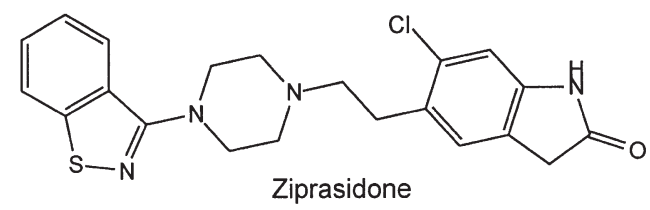

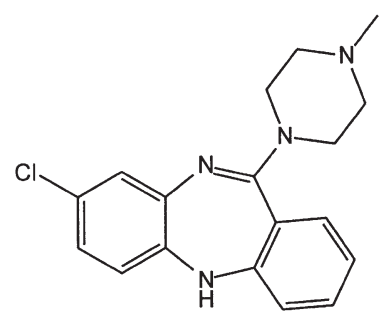

Clozapine

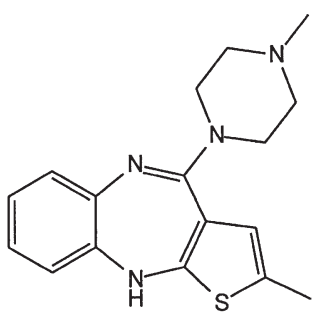

Olanzapine
Figure 1. Structures of ziprasidone, clozapine, and olanzapine. tivity in vitro (Seeger et al. 1995; Schmidt et al. 1998), little is known of the relevance of this activity in vivo or of the comparative activities of clozapine and olanzapine.

In the present study, the ability of ziprasidone, clozapine, and olanzapine to inhibit the spontaneous firing rate of serotonergic dorsal raphe neurons was used as an in vivo marker of 5- $\mathrm{HT}_{1 \mathrm{~A}}$ agonism. Blockade of inhibition by pretreatment with the selective $5-\mathrm{HT}_{1 \mathrm{~A}}$ antagonist WAY-100,635 was employed to confirm mechanism of action. Given the binding affinity for $\alpha_{1}$ sites noted for all three agents (Table 1) and the reported ability of $\alpha_{1}$ antagonists to suppress 5-HT unit activity (Baraban and Aghajanian 1980), sensitivity to reversal by desipramine (DMI), a NE re-uptake inhibitor, was also assessed. A portion of this work was previously presented in abstract form (Reynolds et al. 1997).

\section{MATERIALS AND METHODS}

\section{Electrophysiology}

Extracellular single unit recordings were made in choral hydrate anesthetized male Sprague-Dawley rats (250-350 g) using standard electrophysiological techniques (Sprouse and Aghajanian 1987). Serotonin-containing neurons were identified on-line by their long duration action potentials and slow rhythmic firing rate. Cells with these characteristics in the dorsal raphe nucleus have been confirmed to be 5-HT neurons by intracellular double-labeling (Aghajanian and Vandermaelen 1982). Unit activity was integrated over 10-second periods and continuously plotted as a firing rate histogram. Compounds were administered I.V. in a volume of $1 \mathrm{ml} / \mathrm{kg}$, and the effects on firing rate noted. Animal procedures were approved by the Institutional Animal Care and Use Committee.

\section{Drugs}

Ziprasidone (CP-88,059; 5-\{2-(4-(1,2-benzisothiazol-3-yl)piperazinyl)ethyl\}-6-chloro-1,3-dihdro-2(1H)-indol-2-one hydrochloride hydrate), olanzapine (2-methyl-4-(4-methyl1-piperazinyl)-10H-thieno[2,3-B][1,5]benzodiazepine), desipramine, and WAY-100,635 (N-(2-(4-(2-methoxyphenyl)-1-piperazinyl)ethyl-N-(2-pyridinyl)cyclohexane-carboxamide trihydrochloride) were synthesized at Pfizer Inc., Central Research Division, Groton, CT. Clozapine (8-chloro-11-(4-methyl-1-piperazinyl)-5H-dibenzo$[\mathrm{b}, \mathrm{e}][1,4]$-diazepine) was purchased from RBI (Natick, MA). Vehicles used for I.V. injections were 5\% DMSO in acid/saline for ziprasidone, olanzapine, and clozapine, and acid/saline for desipramine and WAY-100,635. Neither of these appeared to have any effect on firing rate by themselves. 


\section{RESULTS}

\section{Inhibition of Serotonin-Containing Dorsal Raphe Cell Firing by Ziprasidone, Clozapine, and Olanzapine}

With a baseline period of stable cell firing established in the dorsal raphe nucleus, bolus intravenous injection of ziprasidone, clozapine, or olanzapine caused a slowing of unit activity (Figure 2). In general, the onset of the inhibition occurred within the first minute following drug administration; recovery was gradual and firing rates often did not return to baseline levels. Dose response curves reveal complete or nearly complete inhibition for each drug at the highest dose tested (Figure 3). Slowing of cell firing was dose-dependent with $\mathrm{ED}_{50}$ values calculated to be $300 \mu \mathrm{g} / \mathrm{kg}$ for ziprasidone, 250 $\mu \mathrm{g} / \mathrm{kg}$ for clozapine, and $1000 \mu \mathrm{g} / \mathrm{kg}$ for olanzapine. Non-linear dose response analysis of the regression coefficients corresponding to the slope of the linear portion of the curves yielded significant differences be-
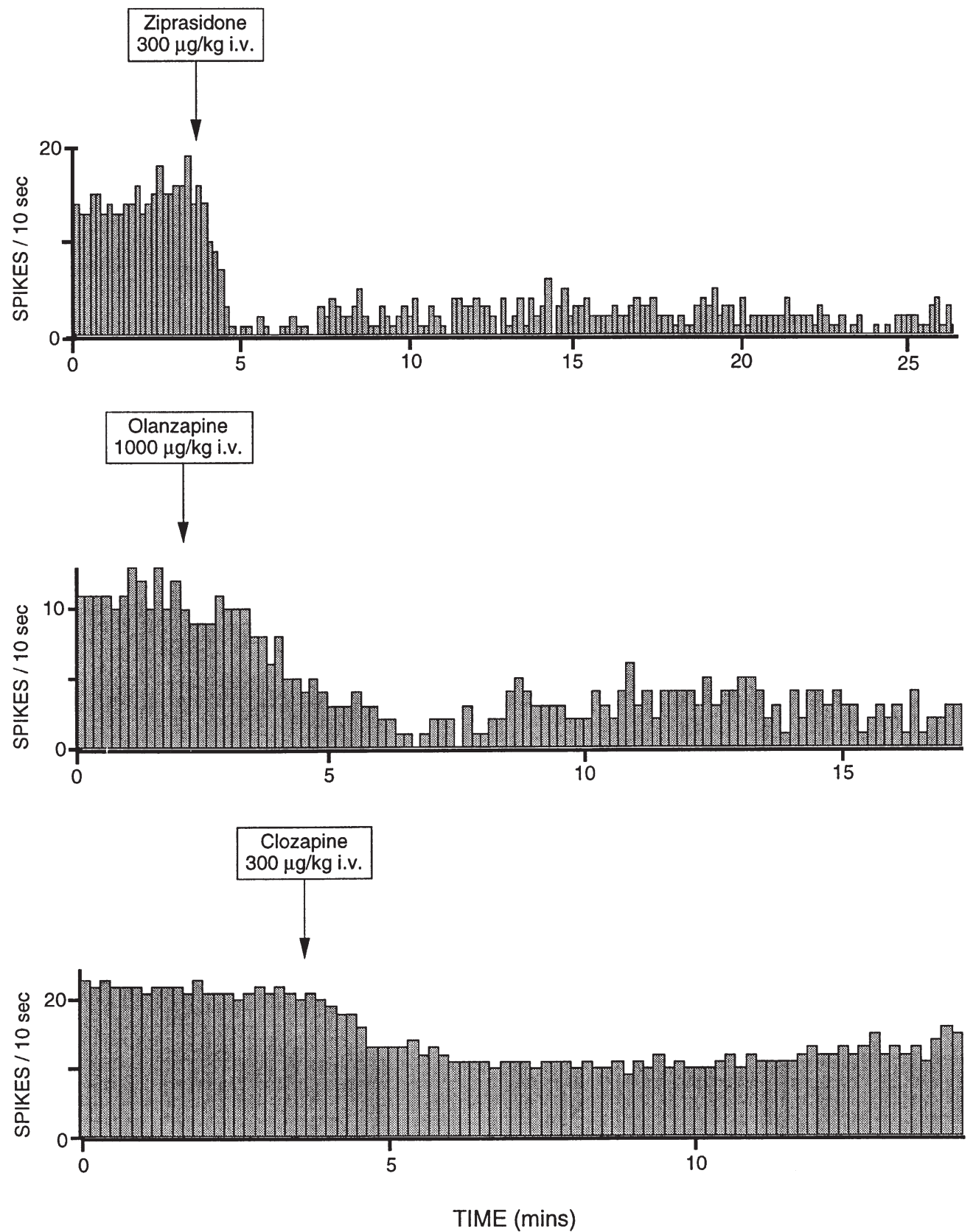

Figure 2. Rate histograms showing the effect of ziprasidone (top), olanzapine (middle), and clozapine (bottom) on the firing of single dorsal raphe serotonergic neurons. In each case, firing was slowed shortly after the intravenous injection; recovery to the baseline rate was gradual and often incomplete. 


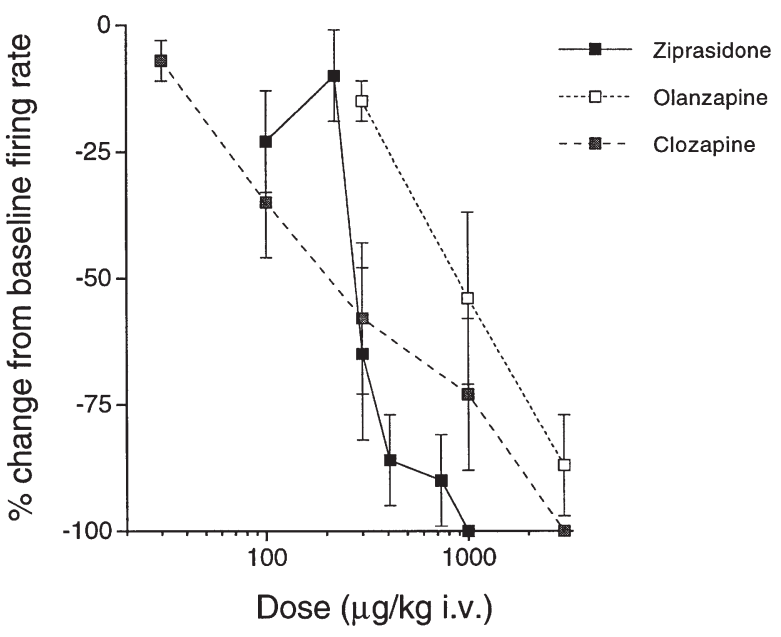

Figure 3. Dose-response curves for ziprasidone, clozapine, and olanzapine to inhibit serotonin neuronal firing. Data are expressed as the mean \pm SEM percentage change from the baseline firing rate $(n=3-8)$. The $\mathrm{ED}_{50}$ for ziprasidone was calculated to be $300 \mu \mathrm{g} / \mathrm{kg}$, for clozapine $250 \mu \mathrm{g} / \mathrm{kg}$, and for olanzapine $1000 \mu \mathrm{g} / \mathrm{kg}$, I.V.

tween the slope for ziprasidone and those for olanzapine and clozapine $(p<.05)$ (Figure 3). The slopes for olanzapine and clozapine were not significantly different from one another according to this analysis $(p>.05)$.

\section{Sensitivity of drug-induced neuronal inhibition to WAY-100,635 and desipramine}

A 2-5-minute pretreatment with the 5- $\mathrm{HT}_{1 \mathrm{~A}}$ antagonist WAY-100,635 $(10 \mu \mathrm{g} / \mathrm{kg}, \mathrm{I} . \mathrm{V}$.$) blocked ziprasidone-$ induced inhibition of serotonin neuronal firing when given at its $\mathrm{ED}_{50}$ value in six of six cells tested (Figure 4). The same dose of WAY-100,635, however, was ineffective against clozapine- or olanzapine-induced slowing of unit activity. Based on their binding affinities, ziprasidone, clozapine, and olanzapine each may act through $\alpha_{1}$ receptors (Table 1), antagonists of which are known to inhibit serotonin neuronal firing (Baraban and Aghajanian 1980). Desipramine (DMI) has recently been shown to reverse the inhibitory effect of $\alpha_{1}$ antagonists on unit activity (Gartside et al. 1997); earlier work had demonstrated similar antagonism with l-amphetamine (Gallager and Aghajanian 1976a) or cirazoline, an $\alpha_{1}$ agonist (Lejeune et al. 1994). In the present study, DMI (5 mg/kg, I.V.) had no discernable effect on the inhibition produced by ziprasidone but reversed that produced by both clozapine and olanzapine (Figure 5). From these data, a profile can be constructed (Figure 6), suggesting a mechanism of action for each agent, namely, $5-\mathrm{HT}_{1 \mathrm{~A}}$ receptor agonism for ziprasidone and $\alpha_{1}$ receptor antagonism for clozapine and olanzapine. By themselves WAY-100,635 and DMI had minimal effects on dorsal raphe neuronal firing (Figures 4 and 5).

\section{DISCUSSION}

Inhibition of serotonin neuronal firing by agents with appreciable affinity for $5-\mathrm{HT}_{1 \mathrm{~A}}$ receptors has long been taken as a measure of $5-\mathrm{HT}_{1 \mathrm{~A}}$ autoreceptor activation and, for the compound under study, central $5-\mathrm{HT}_{1 \mathrm{~A}}$ agonism. Early work noted the ability of LSD and 5-HT itself to slow neuronal firing (Aghajanian et al. 1972); later more selective $5-\mathrm{HT}_{1 \mathrm{~A}}$ receptor agents, led in large part by 8-OH-DPAT, were employed to establish the receptor subtype of the somatodendritic autoreceptors known to modulate firing rate (deMontigny et al. 1984; VanderMaelen et al. 1986; Sprouse and Aghajanian 1987). Clearly, however, the most compelling evidence for $5-\mathrm{HT}_{1 \mathrm{~A}}$ receptor-mediated inhibition lay in the blockade or reversal of the agonist-induced response by first non-selective 5- $\mathrm{HT}_{1}$ antagonists (Sprouse and Aghajanian 1986; Lum and Piercey 1988) and later by low efficacy compounds selective for the $5-\mathrm{HT}_{1 \mathrm{~A}}$ subtype among the family of 5-HT receptors (Arborelius et al. 1994; Fletcher et al. 1994; Fornal et al. 1996). As a result, new agents, outside of the prototypical class, can be regarded as $5-\mathrm{HT}_{1 \mathrm{~A}}$ receptor agonists by virtue of their ability to mimic the inhibitory actions of $8-\mathrm{OH}-$ DPAT on serotonin neuronal firing and the sensitivity of such inhibition to $5-\mathrm{HT}_{1 \mathrm{~A}}$ receptor antagonists. The precise mechanism of inhibition, however, requires further dissection as there is accumulating evidence for the existence of postsynaptic $5-\mathrm{HT}_{1 \mathrm{~A}}$ receptors in forebrain which modulate serotonin neuronal firing by a long feedback loop, essentially adding to that achieved by direct activation of $5-\mathrm{HT}_{1 \mathrm{~A}}$ cell body autoreceptors (Ceci et al. 1994; Hajós and Sharp 1998). Nevertheless, by either mechanism, 5-HT receptor agonists that inhibit 5-HT neuronal activity are $5-\mathrm{HT}_{1 \mathrm{~A}}$ agonists.

All three compounds examined in this study, ziprasidone, clozapine, and olanzapine, inhibited serotonin neuronal firing. Inhibition in each case was dose-dependent with complete (or in the case of olanzapine, nearly complete) inhibition attained at the highest dose tested. Pretreatment with the $5-\mathrm{HT}_{1 \mathrm{~A}}$ receptor antagonist WAY-100,635 (Fletcher et al. 1994) blocked inhibition due to the ziprasidone challenge alone; however, inhibition produced by clozapine or olanzapine was unaffected by an identical dose of WAY-100,635 (Figure 6). Based on this pattern of activity, ziprasidone appears to be a centrally acting $5-\mathrm{HT}_{1 \mathrm{~A}}$ agonist, whereas the other two do not, within the dose range examined. This interpretation is consistent with earlier work demonstrating the affinity of ziprasidone for $5-\mathrm{HT}_{1 \mathrm{~A}}$ receptor sites $\left(\mathrm{K}_{\mathrm{i}}=3.4 \mathrm{nM}\right)($ Table 1$)$ compared to clozapine $\left(\mathrm{K}_{\mathrm{i}}=120\right.$ 

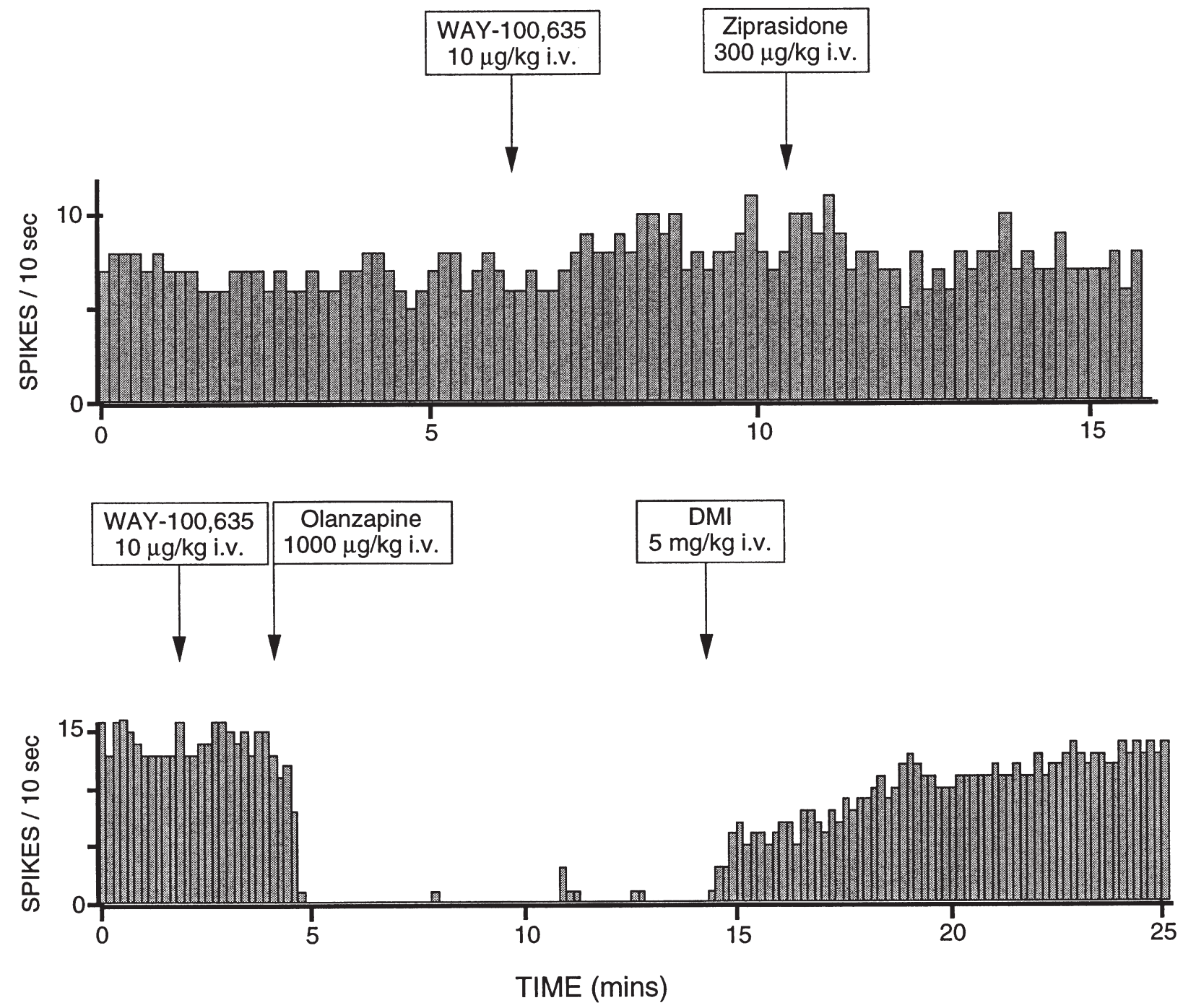

Figure 4. Rate histograms showing the effect of pretreatment with the 5- $\mathrm{HT}_{1 \mathrm{~A}}$ antagonist WAY-100,635 (10 $\mu \mathrm{g} / \mathrm{kg}, \mathrm{I} . \mathrm{V}$.) on the inhibition of serotonin neuronal firing produced by ziprasidone (top) and olanzapine (bottom) given I.V. at their ED 50 values. WAY-100,635 pretreatment blocked the inhibition produced by ziprasidone but had no effect on that produced by olanzapine. Instead, a subsequent dose of the NE re-uptake blocker desipramine (DMI; $5 \mathrm{mg} / \mathrm{kg}$, I.V.) reversed the olanzapine-induced inhibition in this example.

$\mathrm{nM})$ and olanzapine $\left(\mathrm{K}_{\mathrm{i}}=2800 \mathrm{nM}\right)$, and its agonist profile in measures of cAMP production (Seeger et al. 1995). Divergent mechanisms among the three compounds tested also follows from the difference in slopes of the dose response curves for ziprasidone vs. olanzapine and clozapine (Figure 3). Although ziprasidone's agonist activity at $5-\mathrm{HT}_{1 \mathrm{~A}}$ receptors is clear, the present experiments do not address its site of action, whether directly on cell body autoreceptors or on forebrain receptors which feedback onto the raphe serotonin neurons. There is also the possibility that the reported 5-HT re-uptake blocking property of ziprasidone might account for its inhibitory action on raphe unit activity given that this mechanism would also be sensitive to
WAY-100,635 blockade. The relative affinity of ziprasidone for the $5-\mathrm{HT}_{1 \mathrm{~A}}$ receptor vs. the 5-HT transporter, however, argues against this idea $\left(\mathrm{K}_{\mathrm{i}}=3.4\right.$ vs. $\left.51 \mathrm{nM}\right)$ as does its $5-\mathrm{HT}_{1 \mathrm{~A}}$ agonist activity in vitro (Seeger et al. 1995).

A reduction in neuronal firing by ziprasidone should lead to a reduction in 5-HT release in raphe projection areas as has been shown for other $5-\mathrm{HT}_{1 \mathrm{~A}}$ agonists (Sharp et al. 1989). The net effect on serotonergic neurotransmission, however, is unknown as the direct effects of ziprasidone on postsynaptic $5-\mathrm{HT}_{1 \mathrm{~A}}$ receptorsincluding those involved in the forebrain feedback loop-would circumvent its actions at somatodendritic autoreceptors (Sprouse and Wilkinson 1995). While the 

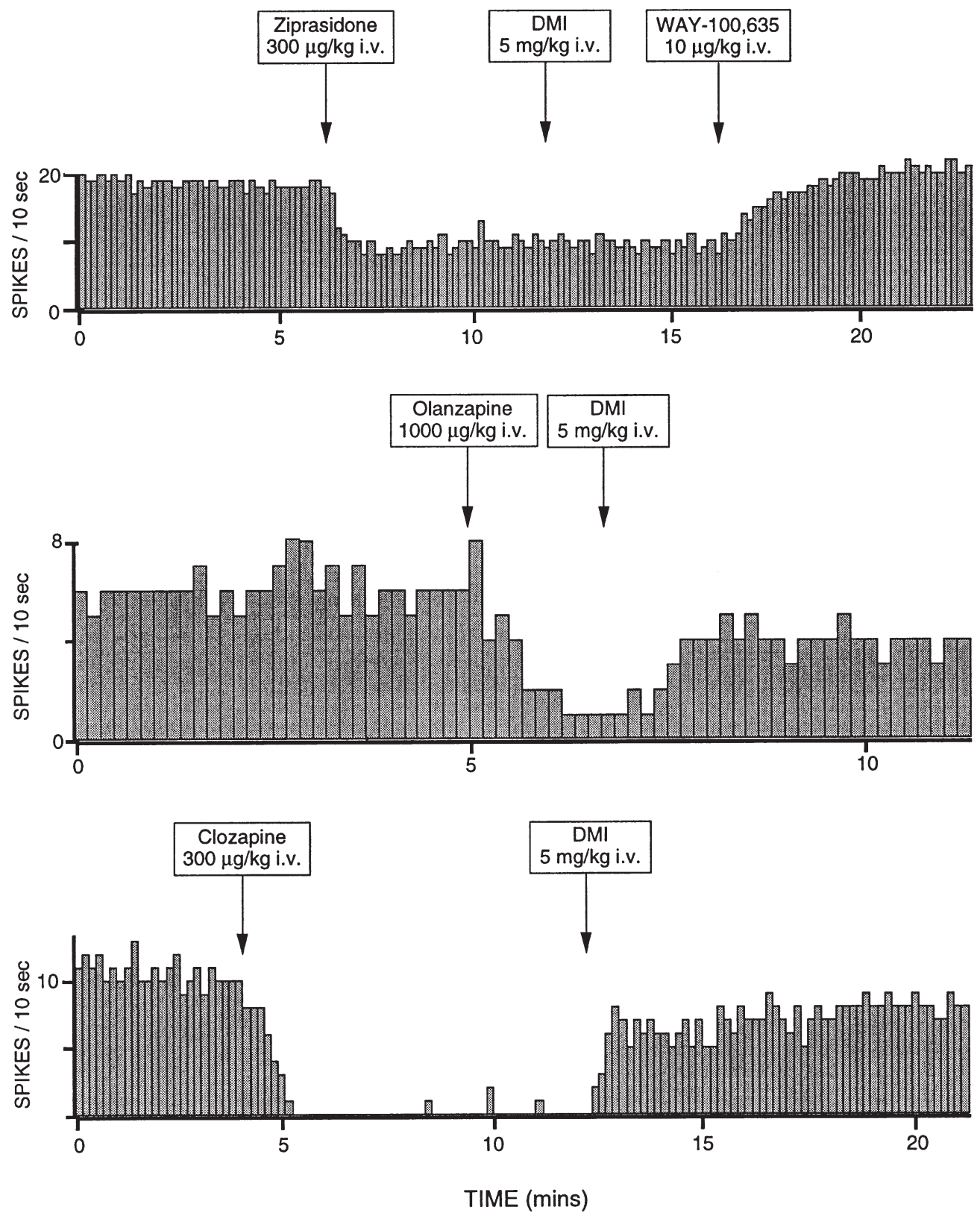

Figure 5. Rate histograms showing the effect of the NE re-uptake blocker desipramine (DMI; $5 \mathrm{mg} / \mathrm{kg}$, i.v.) on the inhibition of serotonin neuronal firing produced by ziprasidone (top), olanzapine (middle), and clozapine (bottom) given I.V. at or near their $\mathrm{ED}_{50}$ values. DMI had little effect on the inhibition produced by ziprasidone but significantly reversed that produced by olanzapine or clozapine. Following the DMI dose in the ziprasidone-treated neuron, WAY-100,635 was able to completely reverse the inhibition (top).

direct effects of ziprasidone on postsynaptic $5-\mathrm{HT}_{1 \mathrm{~A}}$ receptors were not assessed in the present study, such activity may be again inferred from the in vitro functional measures of adenylate cyclase activity, in this case in guinea pig hippocampus (Seeger et al. 1995). It remains for other investigators to determine the effects of chronic ziprasidone administration on 5-HT neurotransmission, with the potential for changes in sensitivity of both cell body autoreceptors and postsynaptic
5- $\mathrm{HT}_{1 \mathrm{~A}}$ receptors. Olanzapine, while it also slows serotonin neuronal firing, differs from ziprasidone in that it is unlikely that it will enhance $5-\mathrm{HT}_{1 \mathrm{~A}}$ neurotransmission as it is a poor ligand for $5-\mathrm{HT}_{1 \mathrm{~A}}$ sites $\left(\mathrm{K}_{\mathrm{i}}=2800\right.$ nM) (Table 1). Instead serotonergic input will be decreased following olanzapine administration and remain uncompensated at postsynaptic $5-\mathrm{HT}_{1 \mathrm{~A}}$ receptors.

Given the similarity in binding affinities for 8-OHDPAT and ziprasidone $\left(\mathrm{K}_{\mathrm{i}}=1.0,3.4 \mathrm{nM}\right.$, respectively), 

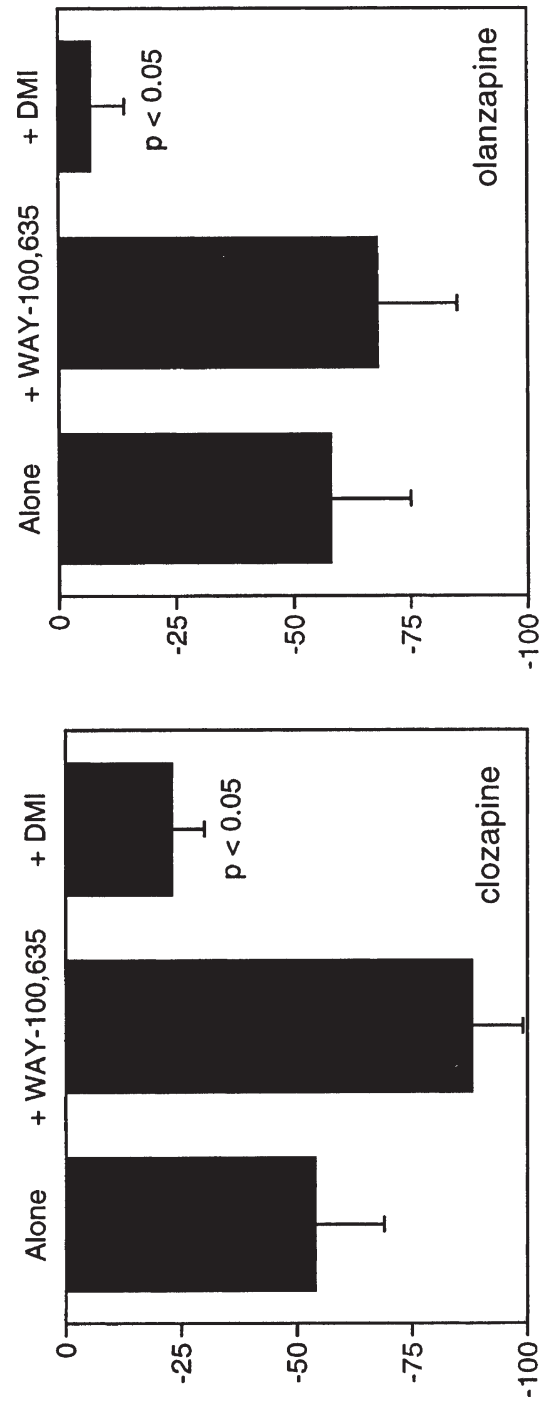

先

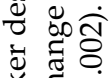

ปี ปี

$\left.\frac{0}{0}\right)^{\circ}$

ษ

표 छे

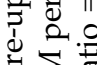

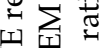

乙造选

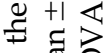

ठี ญ

ชิ \& 4

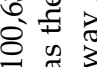

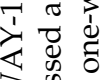

का

至

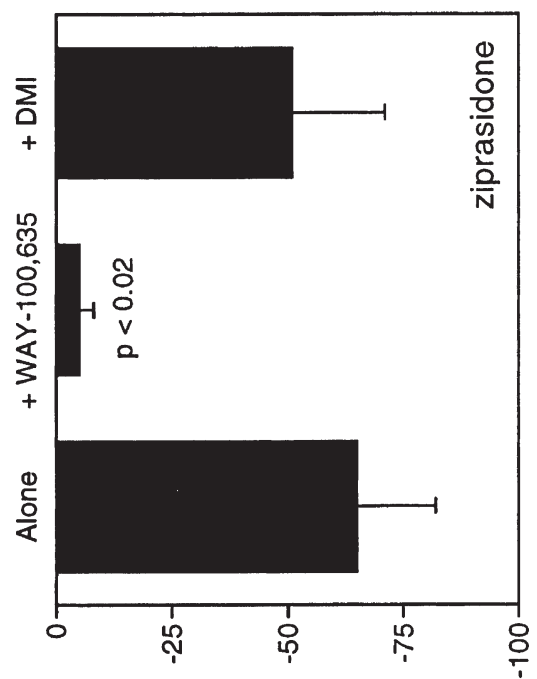

әред 6u!ı! әu!|әseq سод! әбиечо \%

记 $\frac{\pi}{\pi}$

$\varangle \sigma^{\circ}$

I

过 छี

莒

苞寻

㝳

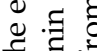

60 눙

全㝴.

당ํㅇ

कृ. 율

50

츠 중 
one might predict similar potency in inhibiting raphe unit activity. The value calculated in the present study $\left(\mathrm{ED}_{50}=300 \mu \mathrm{g} / \mathrm{kg}\right.$, I.V.), in fact, is far greater than that reported earlier for 8-OH-DPAT $(1.1 \mu \mathrm{g} / \mathrm{kg}$, I.V.) (Sprouse et al. 1995). Such a discrepancy might be the result of ziprasidone's multiple receptor actions given its reported activities at serotonergic, adrenergic, and dopaminergic receptors and transporters (Seeger et al. 1995). Alternatively, the difference in predicted potency might lead to the conclusion that ziprasidone is a weak agonist at $5-\mathrm{HT}_{1 \mathrm{~A}}$ receptors since potency and intrinsic activity are known to vary inversely in regions such as the raphe nuclei with high receptor reserve (Cox et al. 1993; Sprouse, 1991; Sprouse and Wilkinson 1995). Other data (Zorn et al. 1999), however, strongly argue against this conclusion. In these studies, large increases in cortical levels of extracellular DA were observed for ziprasidone, equivalent to those for 8-OH-DPAT, and sensitive to WAY-100,635 pretreatment. These findings, together with its robust inhibition of $5-\mathrm{HT}_{1 \mathrm{~A}}$-mediated cAMP production (Seeger et al. 1995), suggest that ziprasidone is a highly efficacious $5-\mathrm{HT}_{1 \mathrm{~A}}$ agonist in vitro and in vivo. That the inhibition of unit activity is not mediated by direct activation of $5-\mathrm{HT}_{1 \mathrm{~A}}$ receptors but by blockade of the 5-HT re-uptake carrier might also explain the discrepancy in potency between ziprasidone and 8-OH-DPAT. However, were potency calculated on the basis of affinity for the 5-HT transporter a much larger value for ziprasidone would have been predicted. For example, fluoxetine inhibits serotonin neuronal firing within a higher dose range than that observed for ziprasidone $\left(\mathrm{ED}_{50}=1800 \mu \mathrm{g} / \mathrm{kg}, \mathrm{I} . \mathrm{V}\right.$.) (Cunningham and Lakoski 1990), and yet is somewhat more potent with regard to affinity for the 5-HT transporter $\left(\mathrm{K}_{\mathrm{i}}=14\right.$ vs. $\left.51 \mathrm{nM}\right)$ (Bolden-Watson and Richelson 1993; Seeger et al. 1995). So too, paroxetine inhibits serotonin neuronal firing within the same dose range as ziprasidone $\left(\mathrm{ED}_{50}=211 \mathrm{vs} .300 \mu \mathrm{g} / \mathrm{kg}\right.$, I.V.) (Lavoie et al. 1997), and yet displays much higher affinity for the 5-HT transporter $\left(\mathrm{K}_{\mathrm{i}}=0.04\right.$ vs. $\left.51 \mathrm{nM}\right)$. Perhaps, the simplest explanation for the lower than predicted potency for ziprasidone is its low free fraction $(<0.10 \%)$ noted in plasma protein binding measurements (Smolarek and Morse 1995; Aweeka et al. 1997).

Earlier work documented the ability of $\alpha_{1}$ antagonists to suppress serotonin neuronal firing and that of agonists or catecholamine-releasing agents to reverse this effect (Gallager and Aghajanian 1976a; Baraban and Aghajanian 1980). Whereas 5- $\mathrm{HT}_{1 \mathrm{~A}}$ autoreceptors are located directly on raphe cell bodies and/or dendrites, $\alpha_{1}$ receptors are thought to reside on GABA interneurons within the dorsal raphe nucleus which in turn impinge on the 5-HT-containing neurons (Gallager and Aghajanian 1976b). In this arrangement, $\alpha_{1}$ antagonists block the inhibitory action of NE on the GABA interneuron; the resultant increase in GABA tone favors in- hibition of raphe neuronal firing. Such a mechanism has been proposed for clozapine which has been examined in numerous laboratories with generally the same findings-dose-dependent inhibition of serotonin neuronal firing and reversal of its effect by agents which increase noradrenergic tone, l-amphetamine (Gallager and Aghajanian 1976a), the $\alpha_{1}$ agonist cirazoline (Lejeune et al. 1994) and DMI.

$5-\mathrm{HT}_{1 \mathrm{~A}}$ antagonists, in contrast, have little effect on clozapine-induced inhibition examined initially with (-)-tertatolol (Lejeune et al. 1994) and now with WAY100,635 . Extending this paradigm to include olanzapine yields a profile identical to clozapine, a finding anticipated from the relative selectivity of clozapine and olanzapine for $\alpha_{1}$ vs. $5-\mathrm{HT}_{1 \mathrm{~A}}$ binding (Table 1). Of the three agents, only ziprasidone has greater affinity for $5-\mathrm{HT}_{1 \mathrm{~A}}$ sites and this selectivity is borne out by its blockade by WAY-100,635. Somewhat at odds with these results are the increases in cortical DA release observed which are elicited by clozapine and partially blocked by WAY-100,635 (Rollema et al. 1997; Zorn et al. 1999). These data suggest that changes in serotonin neuronal firing do not underly the effects on DA release observed in the cortex and that the binding affinity of clozapine for $5-\mathrm{HT}_{1 \mathrm{~A}}$ receptors, while lower than that for $\alpha_{1}$ sites, nevertheless can be of significance at sufficiently high doses. Indeed, the ability of DMI in the present study to reverse the effects of clozapine may be a partial effect (compared to olanzapine) such that at higher doses the inhibition of cell firing observed may be a combination of $\alpha_{1}$ antagonism and $5-\mathrm{HT}_{1 \mathrm{~A}}$ agonism (Figure 6).

With a binding affinity at $\alpha_{1}$ sites in the range of that observed for clozapine and olanzapine, it is curious that the inhibitory action of ziprasidone on dorsal raphe neurons does not involve at least in part $\alpha_{1}$ antagonism. WAY-100,635 pretreatment appears to provide nearly complete blockade of ziprasidone-induced inhibition, whereas DMI appears to have little effect (Figure 6). One possible explanation is that $5-\mathrm{HT}_{1 \mathrm{~A}}$ receptor activation produces complete inhibition of raphe unit activity at doses lower than that required for engagement of an $\alpha_{1}$ mechanism. A similar reasoning applies to the anxiolytic/antidepressant ipsapirone with its low $\alpha_{1}: 5$ $\mathrm{HT}_{1 \mathrm{~A}}$ selectivity ratio (Peroutka 1985); inhibition of serotonin neuronal firing in this case is completely blocked by (-)-propranolol acting as a $5-\mathrm{HT}_{1 \mathrm{~A}}$ antagonist (Sprouse and Aghajanian 1986). An alternative explanation involves the reported NE re-uptake blocking property of ziprasidone $\left(\mathrm{K}_{\mathrm{i}}=50 \mathrm{nM}\right.$ ) (Seeger et al. 1995) which, as demonstrated in the present study in the form of DMI can mitigate the effects of $\alpha_{1}$ antagonism.

Beyond a 5- $\mathrm{HT}_{1 \mathrm{~A}^{-}}$or $\alpha_{1}$-mediated mechanism for the observed inhibitory effect of ziprsidone on dorsal raphe unit firing, other aspects of its pharmacology may play 
a role. Ziprasidone's action as a $5-\mathrm{HT}_{1 \mathrm{D}}$ antagonist (Seeger et al. 1995) may increase GABA release from interneurons within the raphe as has been reported for other antagonists in human cortex (Feuerstein et al. 1996). Such an action would seem to be of secondary importance, however, as WAY-100,635 produced nearly complete blockade of inhibition. As a 5- $\mathrm{HT}_{1 \mathrm{D}}$ antagonist ziprasidone might also increase intra-raphe levels of 5-HT through 5- $\mathrm{HT}_{1 \mathrm{D}}$ release autoreceptors located on or near the cell bodies (Starkey and Skingle 1994). The excess 5-HT would then activate somatodendritic 5- $\mathrm{HT}_{1 \mathrm{~A}}$ autoreceptors and slow cell firing (Skingle et al. 1995). This mechanism too would seem to contribute little to the effects of ziprasidone on raphe firing since the $5-\mathrm{HT}_{1 \mathrm{D}}$ antagonist GR127935, as a prototype for this class, has been shown to have little effect on serotonin neuronal firing rate (Sprouse et al. 1997). The 5-HT reuptake blocking property of ziprasidone (Seeger et al. 1995) would also increase intra-raphe 5-HT and lead to a slowing of neuronal activity, a mechanism similarly sensitive to $5-\mathrm{HT}_{1 \mathrm{~A}}$ antagonism. In the absence of any additional data to support this possibility, it is assumed that ziprasidone's more potent affinity for $5-\mathrm{HT}_{1 \mathrm{~A}}$ sites $\left(\mathrm{K}_{\mathrm{i}}=3.4 \mathrm{nM}\right)$ as compared to 5-HT re-uptake sites $\left(\mathrm{K}_{\mathrm{i}}=\right.$ $51 \mathrm{nM}$ ) favors a 5- $\mathrm{HT}_{1 \mathrm{~A}}$ autoreceptor-mediated action.

The potential clinical benefits of the $5-\mathrm{HT}_{1 \mathrm{~A}}$ agonist activity of ziprasidone are many. 5- $\mathrm{HT}_{1 \mathrm{~A}}$ agonists reduce the dystonia in monkeys (Casey 1994) and prevent the catalepsy in rats (Neal-Beliveau et al. 1993) produced by haloperidol, both models of neuroleptic-induced EPS in humans. Their reported ability to enhance DA neurotransmission suggests an improvement in the negative symptoms of schizophrenia as a regional hypodopaminergia is considered to be causative (Sharma and Shapiro 1996). Antidepressant activity may also follow from $5-\mathrm{HT}_{1 \mathrm{~A}}$ agonist activity based on the clinical experience with buspirone and on the effects of agonists in preclinical models of this disease state (deVry 1995). While ziprasidone possesses activities at numerous receptors implicated in the etiology and treatment of schizophrenia and associated behaviors $\left(\mathrm{D}_{2}, 5-\mathrm{HT}_{2 \mathrm{~A}}\right.$, $5-\mathrm{HT}_{2 \mathrm{C}}, 5-\mathrm{HT}_{1 \mathrm{D}}, 5-\mathrm{HT}$ re-uptake, $\mathrm{NE}$ re-uptake), the 5- $\mathrm{HT}_{1 \mathrm{~A}}$ activity reported here suggests that it is this property which contributes to all of the cardinal features of an ideal antipsychotic-low EPS liability, efficacy against negative symptoms, and relief from associated depression-and potentially distinguishes ziprasidone from currently available antipsychotic agents.

\section{REFERENCES}

Aghajanian GK, Haigler HJ, Bloom FE (1972): Lysergic acid diethylamide and serotonin: Direct actions on serotonin-containing neurons in rat brain. Life Sci 11:615-622

Aghajanian GK, Vandermaelen CP (1982): Intracellular iden- tification of central noradrenergic and serotonergic neurons by a new double labeling procedure. J Neurosci 2:1786-1792

Altar CA, Wasley AM, Neale RF, Stone GA (1986): Typical and atypical antipsychotic occupancy of D2 and S2 receptors: An autoradiographic analysis in rat brain. Brain Res Bull 16:517-525

Arborelius L, Höök BB, Hacksell U, Svensson TH (1994): The $5-\mathrm{HT}_{1 \mathrm{~A}}$ antagonist (S)-UH-301 blocks the (R)-8-OHDPAT-induced inhibition of serotonergic dorsal raphe cell firing in the rat. J Neural Trans 96:179-186

Aweeka F, Horton M, Swan S, Wilner KD, Sherwood J, Anziano R (1997): The pharmacokinetics of ziprasidone in subjects with normal and impaired renal function. Eur Neuropsychopharmacol 7:S214

Baraban JM, Aghajanian GK (1980): Suppression of firing activity of 5-HT neurons in the dorsal raphe by alphaadrenoceptor antagonists. Neuorpharmacology 19:355363

Bolden-Watson C, Richelson E (1993): Blockade by newlydeveloped antidepressants of biogenic amine uptake into rat brain synaptosomes. Life Sci 52:1023-1029

Casey DE (1994): Extrapyramidal syndromes: Primate models as predictors of clinical response. Neuropsychopharmacology 10:S370

Ceci A, Baschirotto A, Borsini F (1994): The inhibitory effect of $8-\mathrm{OH}-\mathrm{DPAT}$ on the firing activity of dorsal raphe serotoninergic neurons in rats is attenuated by lesion of the frontal cortex. Neuropharmacology 33:709-713

Cox RF, Meller E, Waszczak BL (1993): Electrophysiological evidence for a large receptor reserve for inhibition of dorsal raphe cell firing by $5-\mathrm{HT}_{1 \mathrm{~A}}$ agonists. Synapse 14:297-304

Cunningham KA, Lakoski JM (1990): The interaction of cocaine with serotonin dorsal raphe neurons. Singleunit extracellular recording studies. Neuropsychopharmacology 3:41-50

deMontigny C, Blier P, Chaput Y (1984): Electrophysiologically-identified serotonin receptors in the rat CNS. Effect of antidepressant treatment. Neuropharmacology 23:1511-1520

deVry J (1995): 5- $\mathrm{HT}_{1 \mathrm{~A}}$ receptor agonists: Recent developments and controversial issues. Psychopharmacology 121:1-26

Fletcher A, Bill DJ, Cliffe EA, Forster EA, Jones D, Reilly Y (1994): A pharmacological profile of WAY-100635, a potent and selective $5-\mathrm{HT}_{1 \mathrm{~A}}$ receptor antagonist. $\mathrm{Br} \mathrm{J}$ Pharmacol 112:91P

Feuerstein TJ, Hüring $\mathrm{H}$, van Velhoven V, Lücking $\mathrm{CH}$, Landwehrmeyer GB (1996): 5- $\mathrm{HT}_{1 \mathrm{D}}$-like receptors inhibit the release of endogenously formed [ $\left.{ }^{3} \mathrm{H}\right] \mathrm{GABA}$ in human, but not in rabbit, cortex. Neurosci Lett 209:210-214

Fornal CA, Metzler CW, Gallegos RA, Veasey SC, McCreary AC, Jacobs BL (1996): WAY-100635, a potent and selective 5-hydroxytryptamine1A antagonist, increases serotonergic neuronal activity in behaving cats: Comparison with (S)-WAY-100135. J Pharmacol Exp Ther 278:752-62

Gallager DW, Aghajanian GK (1976a): Effect of antipsychotic drugs on the firing of dorsal raphe cells. I. Role of adrenergic system. Eur J Pharmacol 39:341-355 
Gallager DW, Aghajanian GK (1976b): Effect of antipsychotic drugs on the firing of dorsal raphe cells. II. Reversal by picrotoxin. Eur J Pharmacol 39:357-364

Gartside SE, Umbers V, Sharp T (1997): Inhibition of 5-HT cell firing in the DRN by non-selective 5-HT reuptake inhibitors: Studies on the role of $5-\mathrm{HT}_{1 \mathrm{~A}}$ autoreceptors and noradrenergic mechanisms. Psychopharmacology 130:261-268

Hajós M, Sharp T (1998): Afferent regulation of dorsal raphe 5-HT neurones: Possible role of cortical postsynaptic 5$\mathrm{HT}_{1 \mathrm{~A}}$ receptors. Soc Neurosci Abstr 24:1108

Howard HR, Lowe III JA, Seeger TF, Seymour PA, Zorn SH, Maloney PR, Ewing FE, Newman ME, Schmidt AW, Furman JS, Robinson GL, Jackson E, Johnson C, Morrone J (1996): 3-Benzisothiazolylpiperazine derivatives as potential aytpical antipsychotic agents. J. Med Chem 39:143-148

Lavoie N, deMontigny C, Debonnel G, Béique JC (1997): Affinities of reuptake inhibitors for the 5-HT and NE carriers: Correlation with their affinities for suppressing the firing activity of 5-HT and NE neurons. Soc Neurosci Abstr 23:1109

Lejeune F, Audinot V, Gobert A, Rivet J-M, Spedding M, Millan M (1994): Clozapine inhibits serotonergic transmission by an action at $\alpha_{1}$-adrenoceptors not at $5-\mathrm{HT}_{1 \mathrm{~A}}$ receptors. Eur J Pharmacol 260:79-83

Lum JT, Piercey MF (1988): Electrophysiological evidence that spiperone is an antagonist of $5-\mathrm{HT}_{1 \mathrm{~A}}$ receptors in the dorsal raphe nucleus. Eur J Pharmacol 149:9-15

Meltzer HY (1995): Atypical antipsychotic drugs. In Bloom FE, Kupfer DJ (eds), Psychopharmacology: The Fourth Generation of Progress. New York, Raven Press, pp 1277-1286

Meltzer HY, Matsubara S, Lee JC (1989): Classification of typical and atypical antipsychotic drugs on the basis of dopamine $\mathrm{D}_{1}, \mathrm{D}_{2}$ and serotonin $\mathrm{p}_{2} \mathrm{pKi}$ values. J Pharmacol Exp Ther 251:238-246

Neal-Beliveau BS, Joyce JN, Lucki I (1993): Serotonergic involvement in haloperidol induced catalepsy. J Pharmacol Exp Ther 265:207-217

Newman-Tancredi A, Chaput C, Verriele L, Millan MJ (1996): Clozapine is a partial agonist at human $5-\mathrm{HT}_{1 \mathrm{~A}}$ receptors. Neuropharmacology 25:119-121

Peroutka SJ (1985): Selective interaction of novel anxiolytics with 5-hydroxytryptamine $\mathrm{A}_{1 \mathrm{~A}}$ receptors. Biol Psychiatry 20:971-979

Reynolds LS, Braselton JP, Sprouse JS (1997): Ziprasidone, unlike olanzapine, inhibits 5-HT neuronal activity by a 5- $\mathrm{HT}_{1 \mathrm{~A}}$ mechanism. Soc Neurosci Abstr 23:1931

Rollema H, Lu Y, Schmidt AW, Zorn SH (1997): Clozapine increases dopamine release in prefrontal cortex by 5 $\mathrm{HT}_{1 \mathrm{~A}}$ receptor activation. Eur J Pharmacol 338:R3-R5

Schmidt AW, Lebel LA, Johnson CG, Howard HR, Lowe JA, Zorn SH (1998): The novel antipsychotic ziprasidone has a unique human receptor binding profile compared to other agents. Soc Neurosci Abstr 24:2177

Schotte A, Janssen PFM, Gommeren W, Luyten WHML, Van Gompel P, Lesage AS, De Loore K, Leysen JE (1996): Risperidone compared with new and reference antipsy- chotic drugs: In vitro and in vivo receptor binding. Psychopharmacology 124:57-73

Sharma RP, Shapiro LE (1996): The 5- $\mathrm{HT}_{1 \mathrm{~A}}$ receptor system: Possible implications for schizophrenic negative symptomatology. Psychiatry Ann 26:88-92

Seeger TF, Seymour PA, Schmidt AW, Zorn SH, Schulz D, Lebel LA, McLean S, Guanowsky V, Howard HR, Lowe III JA, Heym J (1995): Ziprasidone (CP-88,059): A new antipsychotic with combined dopamine and serotonin receptor antagonist activity. J Pharmacol Exp Ther 275:101-113

Sharp T, Bramwell SR, Grahame-Smith DG (1989): In vivo measurements of brain extracellular 5-hydroxytryptamine using microdialysis: Changes in relation to 5-hydroxytryptaminergic neuronal activity. J Neurochem 53:234-240

Skingle M, Sleight AJ, Feniuk W (1995): Effects of the 5- $\mathrm{HT}_{1 \mathrm{D}}$ receptor antagonist GR127935 on extracellular 5-HT levels in guinea pig frontal cortex as measured by microdialysis. Neuropharmacology 34:377-382

Smolarek TA, Morse T (1995): Pharmacokinetic and disposition studies of ziprasidone, a new antipsychotic. European Conference on Specificity and Variability in Drug Metabolism, Besancon, France

Sprouse J (1991): Inhibition of dorsal raphe cell firing by MDL 73005EF, a novel 5- $\mathrm{HT}_{1 \mathrm{~A}}$ receptor ligand. Eur J Pharmacol 201:163-169

Sprouse JS, Aghajanian GK (1986): (-)-Propranolol blocks the inhibition of serotonergic dorsal raphe cell firing by 5$\mathrm{HT}_{1 \mathrm{~A}}$ selective agonists. Eur J Pharmacol 128:295-298

Sprouse JS, Aghajanian GK (1987): Electrophysiological responses of serotonergic dorsal raphe neurons to 5$\mathrm{HT}_{1 \mathrm{~A}}$ and $5-\mathrm{HT}_{1 \mathrm{~B}}$ agonists. Synapse 1:3-9

Sprouse JS, Wilkinson LO (1995): Innovative therapeutic actions by targeting serotonin 1A receptors selectively. Int Rev Psychiatry 7:5-15

Sprouse J, Clarke T, Reynolds L, Heym J, Rollema H (1995): Comparison of the effects of sertraline and its metabolite desmethylsertraline on blockade of central 5-HT reuptake in vivo. Neuropsychopharmacology 14:225-31

Sprouse J, Reynolds L, Rollema H (1997): Do 5- $\mathrm{HT}_{1 \mathrm{~B} / 1 \mathrm{D}}$ autoreceptors modulate dorsal raphe cell firing? In vivo electrophysiological studies in guinea pigs with GR127935. Neuropharmacology 36:559-567

Starkey SJ, Skingle M (1994): $5-\mathrm{HT}_{1 \mathrm{D}}$ as well as $5-\mathrm{HT}_{1 \mathrm{~A}}$ autoreceptors modulate 5-HT release in the guinea pig dorsal raphe nucleus. Neuropharmacology 33:393-402

VanderMaelen CP, Matheson GK, Wilderman RC, Patterson LA (1986): Inhibition of serotonergic dorsal raphe neurons by systemic and iontophoretic administration of buspirone, a non-benzodiazepine anxiolytic drug. Eur J Pharmacol 129:123-130

Zorn SH, Lebel LA, Schmidt AW, Lu Y, Braselton JP, Reynolds LS, Sprouse JS, Rollema H (1999): Pharmacological and neurochemical studies with the new antipsychotic ziprasidone. In Palomo T, Benninger RJ, Archer T (eds), Interactive Monoaminergic Disorders. Madrid, Spain, Editorial Sintesis, pp 377-393 